\title{
Pengaruh Strategi Pembelajaran Berbasis Masalah dan Minat Belajar Terhadap Kemampuan Berpikir Kritis dan Hasil Belajar Siswa pada Materi Sistem Pencernaan Makanan Manusia di MAS Amaliyah Sunggal
}

\author{
Ridho Fenni Naputri1 ${ }^{1}$ Syarifuddin $^{2}$ Elly Djulia $^{3}$ \\ ${ }^{1}$ Alumni Program Studi Pendidikan Biologi Program Pascasarjana Universitas Negeri Medan, Sumatera Utara, \\ Indonesia \\ ${ }^{2}$ Program Studi Pendidikan Biologi, Program Pascasarjana, Universitas Negeri Medan \\ E-mail: ridhofenni@ymail.com
}

\begin{abstract}
This study was aimed to determine effect on: (1) Problem based learning strategy toward critical thinking skills; (2) Learning interest toward critical thinking skills; (3) Interaction between problem based learning strategy and learning interest toward critical thinking skills; (4) Problem based learning strategy toward students' learning outcomes; (5) Learning interest toward students' learning outcomes; and (6) Interaction between problem based learning strategy and learning interest toward students' learning outcomes. Subjects in this study are taken as much as 3 classes is determined by a cluster random sampling. Determined learning class in research is 2 classes with sample of 38 people per class. . Based on the results show that there are significant effect on (1) Learning model toward critical thinking skills which obtained $\mathrm{F}_{\text {coun }}>\mathrm{F}_{\text {table }}(6,971>2,50)$ and probability value is $0,010<0,05$; (2) Learning interest toward critical thinking skills which obtained $F_{\text {count }}>F_{\text {table }}(24,949>2,50)$ and probability value is $0,000<0,05$; (3) Interaction between learning model and learning interest toward critical thinking skills which obtained $\mathrm{F}_{\text {count }}>\mathrm{F}_{\text {table }}(4,140>2,50)$ and probability value is $0,046<0,05$; (4) Learning model toward students' learning outcomes which obtainde $F_{\text {count }}>F_{\text {table }}(25,269>2,50)$ and probability value is $0,000<0,05$; (5) Learning interest toward students' learning outcomes which obtained $\mathrm{F}_{\text {count }}>\mathrm{F}_{\text {table }}(13,888>2,50)$ and probability value is $0,000<0,05$; and (6) Interaction between learning model and learning interest toward students' learning outcomes which obtained $\mathrm{F}_{\text {count }}>\mathrm{F}_{\text {table }}$ $(4,291>2,50)$ and probability value is $0,042<0,05$. Based on this study can conclude that there are significant effect of strategy, interest, and interaction between learning strategy and learning interest toward critical thinking skills and students' learning outcomes on the topic in digestive system of human at MAS Amaliyah Sunggal. This cases are expected to provide information for teachers and schools to use problem based learning strategy and learning interest to improve critical thinking skills and student's learning outcomes.
\end{abstract}

Key Word: Learning strategy, interest, critical thinking skills, learning outcomes, digestive system.

\section{PENDAHULUAN}

Biologi sebagai salah satu bidang studi IPA merupakan ilmu yang besar perannya dalam pendidikan, di samping itu juga belajar biologi sangat bermanfaat bagi kehidupan sehari-hari. Begitu pentingnya peranan mempelajari biologi maka pemerintah terus berupaya untuk meningkatkan mutu pengajaran mulai dari tingkat Sekolah Menengah Pertama (SMP) sampai Perguruan Tinggi. Membahas kualitas pendidikan tidak terlepas dari pencapaian hasil atau prestasi belajar siswa, karena hasil belajar siswa dapat dijadikan tolak ukur untuk menilai apakah pendidikan di suatu sekolah berhasil atau tidak.

Pembelajaran di kelas saat ini seharusnya tidak hanya sekedar aktivitas proses transfer pengetahuan satu arah dari guru pada siswa, dimana guru sebagai pusat informasi dan siswa sebagai penerima informasi dan bertindak pasif, tetapi merupakan suatu interaksi siswa dengan ilmu pengetahuan yang diinisiasi oleh rasa ingin tahu (curiosity) siswa, proses uji coba (trial and error), analisa konsep atau masalah, dan menyimpulkan suatu konsep ilmu pengetahuan yang difasilitasi oleh guru yang diharapkan dapat menimbulkan diskusi-diskusi menarik antar siswa yang diliputi proses berpikir kompleks, saling mengajari teman (peer teaching), presentasi pendapat dan tanya jawab yang memungkinkan siswa memahami konsepkonsep ilmu pengetahuan sekaligus mengasah keterampilan baik dalam berpikir 
kritis dan memecahkan masalah dan adanya rasa percaya diri siswa terhadap kemampuan yang ia miliki.

Mata pelajaran biologi merupakan pelajaran yang mudah untuk dikaitkan dengan kehidupan sehari-hari. Banyak konsep-konsep dalam biologi yang berhubungan dengan kehidupan sehari-hari. Tetapi pelajaran dianggap sulit dan tidak menarik sebagian siswa.

Minat adalah kecenderungan jiwa yang tetap untuk memperhatikan dan mengenang beberapa aktivitas atau kegiatan (Slameto, 2003). Minat merupakan bagian dari belajar. Dari pengertian minat belajar tersebut tampak tiga hal, yaitu: (1) minat dimulai dengan suatu perubahan tenaga dalam diri seseorang, (2) minat itu ditandai oleh dorongan afektif yang kadang tampak dan kadang sulit diamati, (3) minat ditandai oleh reaksi-reaksi untuk mencapai tujuan. Siswa akan berusaha sekuat tenaga apabila dia memiliki minat yang besar untuk mencapai tujuan belajar. Siswa akan belajar dengan sungguh-sungguh tanpa dipaksa, bila memiliki minat yang besar; yang dengan demikian diharapkan akan mencapai prestasi yang tinggi. Adanya minat berprestasi yang tinggi dalam diri siswa merupakan syarat agar siswa terdorong oleh kemauannya sendiri untuk mengatasi berbagai kesulitan belajar yang dihadapinya, dan lebih lanjut siswa akan sanggup untuk belajar sendiri.

Hal ini juga dapat berdampak kemampuan mengingat materi pelajaran menjadi rendah pula. Sya'roni (2008) di SMP Muhammadiyah 4 CipondohTangerang mendapatkan data bahwa ada pengaruh interaksi antara model pembelajaran dan minat belajar siswa terhadap hasil belajar biologi. Siswa yang memiliki minat belajar tinggi, menyebabkan siswa memiliki hasil belajar yang lebih baik dari pada siswa yang memiliki minat belajar yang rendah. Untuk menghadapi siswa dengan latar belakang minat yang berbeda, maka dirasa perlu untuk menemukan model pembelajaran yang lebih tepat. model pembelajaran PBL diharapkan dapat digunakan dalam meningkatkan minat belajar biologi, hasil belajar biologi dan kemampuan berpikir kritis .

Saat ini, para peneliti bidang pendidikan telah mengembangkan sejumlah teori belajar dan berbagai model pembelajaran yang dinilai baik dalam mendukung suasana pembelajaran aktif. Masalah ini digunakan untuk mengaitkan rasa keingintahuan serta kemampuan siswa analisis siswa dan inisiatif atas materi pelajaran. Pembelajaran berbasis maslah mempersiapkan siswa untuk berpikir kritis dan analitis, dan untuk mencari serta menggunakan sumber pembelajaran yang sesuai.

Menurut Sanjaya (2006) PBM merupakan rangkaian aktivitas pembelajaran yang menekankan kepada proses penyelesaian maslah yang dihadapi secara ilmiah. Terdapat 3 ciri utama dari PBM, Pertama, PBM merupakan rangkaian aktivitas pembelajaran, artinya dalam implementasi PBM ada sejumlah kegiatan yang harus dilakukan siswa. PBM tidak mengharapkan siswa hanya sekedar mendengarkan, mencatat, kemudian menghapal materi pelejaran, akan tetapi melalui PBM siswa aktif berpikir, berkomunikasi mencari dan mengolah data, dan akhirnya menyimpulkan. Kedua, Aktivitas pembelajaran diarahkan untuk menyelesaikan maslah. PBM menempatkan maslah sebagai kata kunci dalam proses pembelajaran. Artinya tanpa maslah tidak mungkin ada proses pembelajaran. Ketiga, pemecahan masalah dilakukan dengan menggunakan pendekatan berpikir secara ilmiah. Berpikir dengan menggunakan metode ilmiah adalah proses berpikir dedukti dan induktif. Proses berpikir ini dilakukan secara sistematis dan empiris.

\section{Kemampuan Berpikir Kritis}

Menurut Amir (2009) di dalam belajar, siswa tidak hanya mendapatkan pasokan pengetahuan, menyimpannya bertumpuktumpuk pada memorinya, jika ia ingin efektif dalam belajar. Siswa perlu memahami apa yang mereka pelajari dan tahu kapan, dimana, dan bagaimana menggunakan pengetahuan tersebut. Keefektifan pembelajaran sangat 
ditentukan oleh tingkat pemahaman awal siswa terhadap materi yang dipelajari. Proses mental yang dominan dalam hal ini harus bergerak hingga diluar informasi yang pernah didengarnya. Misalnya kemampuan berpikir seseorang untuk menemukan solusi baru dari persoalan yang dihadapi saat itu.

Menurut Sanjaya (2006), kemampuan berpikir memerlukan kemampuan mengingat dan memahami, oleh sebab itu kemampuan mengingat adalah bagian terpenting dalam mengembangkan kemampuan berpikir. Artinya belum tentu emosi (afektif), dan kemampuan (konatif) untuk mencapai suatu objek, seseorang suatu soal atau suatu situasi yang bersangkutan dengan diri pribadi (Buchori, 1985). Biologi merupakan ilmu yang mempelajari tentang kehidupan. Semua benda yang hidup menjadi obyek dari biologi. Oleh karena itu biologi berobyekkan benda-benda yang hidup. Maka cukup banyak ilmu-ilmu yang tergabung di dalamnya. Biologi sebagai salah satu bidang ilmu pengetahuan juga merupakan objek pada aspek minat. Dengan demikian, bidang biologi dapat melahirkan reaksi perasaan senang, gembira, dan semangat belajar, begitu pula sebaliknya, tergantung dari kepribadian siswa sendiri apakah menaruh minat yang tinggi terhadap bidang biologi atau tidak (Ahmadi, 1998).

Minat besar pengaruhnya terhadap aktivitas belajar. Siswa yang berminat terhadap biologi akan mempelajari biologi dengan sungguh-sungguh seperti rajin belajar, merasa senang mengikuti penyajian pelajaran biologi, dan bahkan dapat menemukan kesulitan-kesulitan dalam belajar menyelesaikan soal-soal latihan dan praktikum karena adanya daya tarik yang diperoleh dengan mempelajari biologi. Siswa akan mudah menghafal pelajaran yang menarik minatnya. Minat berhubungan erat dengan motivasi. Motivasi muncul karena adanya kebutuhan, begitu juga minat, sehingga tepatlah bila minat merupakan alat motivasi. Proses belajar akan berjalan lancar bila disertai minat. Oleh karena itu, guru perlu membangkitkan minat siswa agar menaruh perhatian secara kontiniyu baik secara sadar maupun tidak pada objek tertentu, biasanya dapat membangkitkan minat pada objek tersebut.

Kalau seorang siswa mempunyai minat pada pelajaran tertentu dia akan memperhatikannya. Namun sebaliknya jika siswa tidak berminat, maka perhatian pada mata pelajaran yang sedang diajarkan biasanya dia malas untuk mengerjakannya. Demikian juga dengan siswa yang tidak menaruh perhatian yang pada mata pelajaran yang diajarkan, maka sukarlah diharapkan siswa tersebut dapat belajar dengan baik. Hal ini tentu mempengaruhi hasil belajarnya (Kartono, 1995). Minat tidak dibawa sejak lahir melainkan diperoleh kemudian. Minat terhadap sesuatu dipelajari sejak lahir melainkan diperoleh kemudian. Minat terhadap sesuatu dipelajari dan mempengaruhi belajar selanjutnya serta mempengaruhi penerimaan minat baru. Jadi minat terhadap sesuatu merupakan hasil belajar dan menyokong belajar selanjutnya walaupun minat terhadap sesuatu hal tidak merupakan hal yang hakiki untuk dapat mempelajari hal tersebut.

Mengembangkan minat terhadap sesuatu pada dasarnya adalah membantu siswa melihat bagaimana hubungan antara materi yang diharapkan untuk dipelajarinya dengan dirinya sendiri sebagai individu. Proses ini berarti menunjukkan pada siswa bagaimana pengetahuan atau kecakapan tertentu mempengaruhi dirinya, melayani tujuan-tujuannya, memuaskan kebutuhan melakukan perubahan situasi kelas dan jadwal pembelajaran. Rancangan penelitian yang digunakan dalam penelitian ini adalah rancangan ekperimen faktorial $2 \times 2$, melalui desain ini akan dibandingkan strategi pembelajaran berbasis masalah dan strategi pembelajaran konvensional ditinjau dari tingkat minat belajarnya terhadap kemampuan berpikir kritis dan hasil belajar biologi siswa. pada masing-masing kelas terdapat siswa yang memiliki minat belajar tinggi dan minat belajar rendah.

Dari wawancara yang dilakukan oleh penulis dengan beberapa siswa kelas XI 
IPA, mereka mengatakan bahwa mereka tidak tertarik dengan pelajaran biologi, karena banyak konsep-konsep yang harus dihapalkan dan istilah-istilah latin yang dianggap membosankan. Di samping itu, pembelajaran pada umumnya masih berlangsung secara konvensional, dimana konsep-konsep transfer secara utuh oleh guru kepada siswa.

Masalah tersebut dapat terlihat pada hasil belajar biologi di MAS Amaliyah Sunggal memiliki jumlah kelas XI sebanyak 3 kelas, rata-rata siswa pada mata pelajaran biologi masih tergolong rendah. Data yang diperoleh menunjukkan bahwa penilaian pada mata pelajaran biologi di MAS Amaliyah Sunggal belum mencapai hasil yang memuaskan. Persentasi hasil ujian siswa MAS Amaliyah Sunggal memiliki nilai dibawah ketuntasan belajar dari tahun pembelajaran 2011/2012 s/d 2013/2014, rata-rata nilai biologi siswa pada ujian akhir semester kelas XI selama kurun waktu tiga tahun terakhir yaitu: (1) tahun ajaran 2012/2013 =65; (2) tahun ajaran $2013 / 2014=68$; (3) tahun ajaran $2014 / 2015=70$, jika dilihat nilai rata-rata hasil belajar Biologi mengalami peningkatan namun peningkatan tersebut belumlah optimal dengan kata lain masih terdapat siswa yang memiliki nilai dibawah kriteria ketuntasan (KKM) yaitu 75 .

Karakteristik siswa dalam penelitian ini minat belajar biologi yang dilakukan oleh siswa itu sendiri untuk berprestasi. Sering dijumpai siswa yang memiliki intelegensi yang tinggi tetapi prestasi belajar yang dicapainya rendah, akibat kemampuan intelektual yang dimilikinya tidak atau kurang berfungsi secara optimal. Salah satu faktor pendukung agar kemampuan intelektual yang dimiliki siswa dapat berfungsi secara optimal adalah adanya minat belajar biologi untuk berprestasi yang tinggi dalam dirinya.

Model pembelajaran yang berpusat pada siswa (student centered) dianggap tepat sebagai solusi terhadap permasalahan untuk meningkatkan hasil belajar biologi dan kemampuan berpikir kritis. Salah satu model pembelajaran yang berpusat pada siswa, yang mampu membangkitkan diskusi, juga dapat meningkatkan kemampuan berpikir kritis dan hasil belajarnya adalah model pembelajaran berbasis masalah atau problem based learning (selanjutnya disingkat menjadi model pembelajaran PBL) (Anderson, 2007). Dalam model pembelajaran PBL, adanya penggunaan masalah sebagai fokus untuk mengembangkan keterampilan pemecahan masalah, materi dan pengaturan diri (Eggen, 2012). Tujuan yang ingin dicapai dalam model pembelajaran PBL ini adalah menumbuhkan kemampuan siswa dalam berpikir kritis, analistis, sistematis dan logis dalam menemukan alternatif pemecahan masalah melalui ekspolarasi data secara empiris dalam rangka menumbuhkan sikap ilmiah (Sanjaya, 2006).

Menurut Barrows dan Kelson (dalam Amir, 2009) Pembelajaran Berbasis Masalah (PBM) berkaitan dengan kurikulum dan proses pembelajaran. Dalam kurikulumnya dirancang masalah-masalah yang menuntut siswa mendapatkan pengetahuan yang penting membuat mereka mahir dalam memecahkan masalah dan memiliki strategi belajar sendiri serta memiliki kecakapan berpartisipasi dalam kelompok. Proses pembelajarannya menggunakan pendekatan sistemik untuk memecahkan masalah atau menghadapi tantangan yang nanti diperlukan dalam karier dan kehidupan sehari-hari.

Dutch (dalam Amir, 2009) mengemukakan bahwa pembelajaran berbasis masalah merupakan metode instruksional yang menantang siswa untuk " belajar dan belajar," bekerja sama dalam kelompok untuk mencari solusi bagi masalah yang nyata. adalah proses berpikir (thinking). Berpikir (thinking) adalah proses mental seseorang yang lebih dari sekedar mengingat (remembering) dan memahami (comprehending), karena mengingat dan memahami lebih bersifat pasif dari pada kegiatan berpikir. Mengingat pada dasarnya hanya melibatkan usaha penyimpanan sesuatu yang telah dialami untuk suatu saat dapat dikeluarkan kembali atas permintaan, memahami memerlukan pemerolehan apa 
yang didengar dan dibaca serta melihat keterkaitan antar aspek dalam memori. Sedangkan berpikir menyebabkan seseorang seseorang yang memiliki kemampuan yang baik dalam mengingat dan memahami juga akan memiliki kemampuan berpikir yang baik. Sebaliknya, kemampuan berpikir seseorang sudah pasti diikuti oleh kemampuan mengingat dan memahami. Hal yang sama dikemukakan oleh Peter Reason (dalam Sanjaya, 2006), bahwa berpikir tidak mungkin terjadi tanpa adanya memori. Bila seseorang kurang memiliki daya ingat (working memori), maka seseorang tersebut tidak mungkin sanggup menyimpan masalah dan informasi yang cukup lama. Jika seseorang kurang memiliki daya ingat jangka panjang (long term memori), maka orang tersebut dipastikan tidak akan memiliki catatan masa lalu yang dapat digunakan untuk memecahkan masalah-masalah yang dihadapi pada masa sekarang. Dengan demikian berpikir sebagai kegiatan yang melibatkan proses mental memerlukan kemampuan mengingat dan memahami.

\section{Minat Belajar Biologi}

Minat adalah kecenderungan jiwa yang tetap untuk memperhatikan dan mengenang beberapa aktivitas atau kegiatan (Slameto, 2003). Seseorang yang berminat terhadap suatu aktivitas dan memperhatikan itu secara konsisten dengan rasa senang. Hal senada juga dinyatakan pula oleh Kartono (1995), minat merupakan moment-moment dari kecenderungan jiwa yang terarah secara intensif kepada suatu obyek yang dianggap paling efektif (perasaan, emosional) yang didalamnya terdapat elemen-elemen efektif (emosi) yang kuat. Minat juga berkaitan dengan kepribadian. Jadi pada minat terdapat unsur-unsur pengenalan (kognitif), pelajaran yang diberikan mudah siswa mengerti (Hasnawiyah, 1994).

Kondisi kejiwaan sangat dibutuhkan dalam proses belajar mengajar. Itu berarti bahwa minat sebagai suatu aspek kejiwaan melahirkan daya tarik tersendiri untuk memperhatikan suatu obyek tertentu.
Berdasarkan hasil penelitian psikologi menunjukkan bahwa kurangnya minat belajar dapat mengakibatkan kurangnya rasa ketertarikan pada suatu bidang tertentu, bahkan dapat melahirkan sikap penolakan kepada guru (Slameto, 2003). Minat merupakan salah satu faktor pokok untuk meraih sukses dalam studi. Penelitianpenelitian di Amerika Serikat mengenai salah satu sebab utama dari kegagalan studi para pelajar menunjukkan bahwa penyebabnya adalah kekurangan minat (Gie, 1998).

Minat melahirkan perhatian spontan yang memungkinkan terciptanya konsentrasi untuk waktu yang lama dengan demikian, minat merupakan landasan bagi konsentrasi. Minat bersifat sangat pribadi, orang lain tidak bisa menumbuhkannya dalam diri siswa, tidak dapat memelihara dan mengembangkan minat itu, serta tidak mungkin berminat terhadap sesuatu hal sebagai wakil dari masing-masing siswa (Gie, 1995).

Minat dan perhatian dalam belajar mempunyai hubungan yang erat sekali. Seseorang yang menaruh minat pada mata pelajaran tertentu, biasanya cenderung untuk memperhatikan mata pelajaran tersebut. Sebaliknya, bila seseorang kebutuhannya. Bila siswa menyadari bahwa belajar merupakan suatu alat untuk mencapai beberapa tujuan yang dianggapnya penting dan bila siswa melihat bahwa dari hasil dari pengalaman belajarnya akan membawa kemajuan pada dirinya, kemungkinan besar siswa akan berminat dan bermotivasi untuk mempelajarinya.

\section{METODE PENELITIAN}

Penelitian dilakukan di MAS Amaliyah Sunggal yang terletak di Jalan Tani Asli Gang Asal Sunggal Medan. Waktu pelaksanaannya pada bulan Januari sampai bulan April 2016. Populasi penelitian ini adalah seluruh siswa kelas XI IPA MAS Amaliyah Sunggal tahun pelajaran 2015/2016 berjumlah 112 orang yang terdiri dari 3 kelas. Pengambilan sampel dilakukan dengan teknik cluster random sampling. Penetapan kelas sampel 
dilakukan dengan mekanisme random sampling, melalui teknik pengundian. Berdasarkan hasil undian pemilihan kelas sampel diperoleh kelas XI IPA ${ }^{1}$ dan kelas XI IPA ${ }^{2}$ yang menjadi sampel penelitian. Selanjutnya dari hasil pengundian pemberian perlakuan diperoleh kelas IPA $^{1}$ sebagai kelas yang memperoleh perlakuan strategi pembelajaran berbasis masalah dan kelas XI IPA ${ }^{2}$ memperoleh perlakuan strategi pembelajaran konvensional.

Penelitian ini merupakan penelitian eksperimen semu (quasi eksperimental research), dengan melakukan eksperimen di dalam kelas yang sudah tersedia sebagaimana adanya, dengan tidak sedangkan soal yang dijawab salah diberi skor 0 (nol). Tes ini digunakan untuk mengukur kemampuan kognitif siswa mengenai pembelajaran materi Sistem Pencernaan Pada Manusia.

\section{Instrumen Penelitian}

Instrumen penelitian yang digunakan adalah bentuk angket dan tes. Angket digunakan untuk mengukur minat belajar siswa dan tes digunakan untuk mengukur kemampuan berpikir kritis dan hasil belajar siswa. Soal tes berisi butir-butir soal yang bertujuan untuk mengukur kemampuan berpikir kritis setelah implementasi pembelajaran (postes), dan hasil belajar siswa sebelum implementasi pembelajaran (pretes) maupun setelah implementasi pembelajaran (postes).

\section{Uji Coba Instrumen}

Responden untuk uji coba instrumen tes kemampuan kognitif diambil dari luar sampel yang setara dengan sampel penelitian, yaitu siswa kelas XII IPA 3 MAS Amaliyah Sunggal. Jumlah sampel yang diambil dalam pengujian instrumen tes kemampuan kognitif sebanyak 36 orang. Uji coba ini bertujuan untuk melihat keabsahan alat pengumpul data, dan untuk itu dilakukan uji validitas, tingkat kesukaran soal, reliabilitas dan daya beda.

Sesuai dengan langkah-langkah pembuatan instrumen seperti yang diuraikan diatas maka untuk pengumpulan data yaitu tes bentuk pilihan ganda (multiple choice). Setiap jawaban benar diberi skor 1 (satu).

\section{HASIL DAN PEMBAHASAN Minat Belajar Siswa}

Minat belajar siswa pada kelas pembelajaran berbasis masalah berdasarkan data dari 38 siswa memiliki rentang skor antara 76 hingga 186 dengan nilai rata-rata sebesar 134,05 dan simpangan baku 41,744. Berdasarkan hasil uji normalitas menggunakan rumus Kolmogorov-Smirnov dipeoleh bahwa data tersebut berdistribusi tidak normal $(\mathrm{P}=0,000<0,05)$. Sedangkan minat belajar siswa pada kelas konvensional berdasarkan data dari 38 siswa memiliki rentang skor antara 67 hingga 176 dengan nilai rata-rata sebesar 120,16 dan simpangan baku 40,415. Berdasarkan hasil uji normalitas menggunakan rumus Kolmogorov-Smirnov dipeoleh bahwa data tersebut berdistribusi tidak normal $(\mathrm{P}=0,000<0,05$. $)$.

\section{Kemampuan Berpikir Kritis Siswa}

Kemampuan berpikir kritis siswa pada kelas pembelajaran berbasis masalah berdasarkan data dari 38 siswa memiliki rentang skor antara 40 hingga 72 dengan nilai rata-rata sebesar 59,47 dan standar error 1,827. Sedangkan kemampuan berpikir kritis siswa pada kelas konvensional berdasarkan data dari 38 siswa memiliki rentang skor antara 31 hingga 72 dengan nilai rata-rata sebesar 52,34 dan standar error 1,652.

\section{Uji Normalitas Hasil Belajar Siswa}

Pengujian dilakukan untuk melihat apakah data hasil terdistribusi secara normal atau tidak. Setelah dilakukan pengolahan data hasil belajar siswa, dapat disimpulkan bahwa tes berdistribusi normal dan tidak normal. Hal tersebut diperjelas dengan hasil perhitungan normalitas pada hasil belajar siswa dengan menggunakan program SPSS 21.0 for windows.

Berdasarkan hasil uji normalitas data hasil belajar siswa menggunakan Kolmogorov-Smirnov, diketahui bahwa data pretes dan postes hasil belajar siswa untuk 
kelas strategi pembelajaran berbasis masalah dengan minat tinggi dan rendah diperoleh nilai signifikansi berdistribusi secara normal $(\mathrm{P}>0,05)$. Data pretes dan postes hasil belajar siswa untuk kelas konvensional dengan minat tinggi diperoleh nilai signifikansi berdistribusi secara normal $(\mathrm{P}>0,05)$. Data pretes hasil belajar siswa untuk kelas konvensional dengan minat rendah diperoleh nilai signifikansi berdistribusi secara normal ( $\mathrm{P}>0,05)$, sedangkan data postes hasil belajar siswa untuk kelas konvensional dengan minat rendah diperoleh nilai signifikansi berdistribusi tidak normal $(\mathrm{P}<0,05)$.

\section{Uji Homogenitas Berpikir Kritis Siswa}

Uji homogenitas menggunakan uji Levene's dengan kriteria pengujian jika signifikansi yang diperoleh $\mathrm{P}>0.05$, maka varians antar pasangan kelompok data homogen dan jika signifikasnsi yang diperoleh $\mathrm{P}<0.05$, maka varians data tidak homogen. Hasil perhitungan homogenitas data berpikir kritis

\section{Hasil Belajar Siswa}

Hasil belajar siswa pada kelas pembelajaran berbasis masalah berdasarkan data dari 38 siswa memiliki rentang skor antara 38 hingga 85 dengan nilai rata-rata sebesar 64,21 dan standar error 1,955. Sedangkan hasil belajar siswa pada kelas konvensional berdasarkan data dari 38 siswa memiliki rentang skor antara 23 hingga 73 dengan nilai rata-rata sebesar 50,18 dan standar error 2,019.

\section{Uji Normalitas Kemampuan Berpikir Kritis Siswa}

Uji normalitas data sebagai syarat analisis kuantitatif. Pengujian ini dilakukan untuk melihat apakah data hasil terdistribusi secara normal atau tidak. Setelah dilakukan pengolahan data kemampuan berpikir kritis siswa, dapat disimpulkan bahwa tes berdistribusi normal dan tidak normal. Hal tersebut diperjelas dengan hasil perhitungan normalitas pada kemampuan berpikir kritis dengan menggunakan program SPSS 21.0 for windows.
Berdasarkan hasil uji normalitas data kemampuan berpikir kritis menggunakan Kolmogorov-Smirnov, diketahui bahwa untuk kelas yang dibelajarkan dengan strategi pembelajaran berbasis masalah dengan minat tinggi diperoleh nilai signifikansi berdistribusi tidak normal $(\mathrm{P}<0,05)$. Sedangkan pembelajaran berbasis masalah dengan minat rendah dan pembelajaran konvensional dengan minat tinggi dan rendah diperoleh nilai signifikansi berdistribusi secara normal $(\mathrm{P}>0,05)$ siswa menggunakan SPSS 21.0 for windows.

Diperoleh Based on Mean nilai signifikansi $0,719>0,05$ maka dapat disimpulkan bahwa kelompok kelas untuk tes kemampuan berpikir kritis siswa memiliki varians yang sama (homogen).

\section{Uji Homogenitas Hasil Belajar Siswa}

Uji homogenitas menggunakan uji Levene's dengan kriteria pengujian jika signifikansi yang diperoleh $\mathrm{P}>0.05$, maka varians antar pasangan kelompok data homogen dan jika signifikasnsi yang diperoleh $\mathrm{P}<0.05$, maka varians data tidak homogen. Hasil perhitungan homogenitas data pretes dan postes hasil belajar siswa menggunakan SPSS 21.0 for windows.

Diperoleh Based on Mean pada data pretes nilai signifikan 0,119>0,05. Sedangkan Based on Mean pada data postes nilai signifikan 0,257>0,05. Hal ini dapat disimpulkan bahwa kelompok kelas untuk tes hasil belajar siswa pada pretes dan postes memiliki varians yang sama (homogen).

\section{Pengujian Hipotesis}

Pengujian hipotesis menggunakan software SPSS 21.0 for windows. Perhitungan yang diperoleh berdasarkan uji ANAVA dua jalur. Dimana nilai signifikansi pada variabel terikat jika memiliki nilai $\mathrm{P}<0,05$ yang berarti ada pengaruh model pembelajaran yang digunakan terhadap variabel terikat. Sedangkan nilai pada variabel terikat jika memiliki nilai $\mathrm{P}>0,05$ yang berarti tidak ada pengaruh model pembelajaran yang digunakan terhadap variabel terikat. 
Berdasarkan data strategi, minat, dan interaksi strategi pembelajaran dengan minat diperoleh nilai signifikan $\mathrm{P}<0,05$ yang berarti bahwa ada pengaruh yang signifikan terhadap kemampuan berpikir kritis siswa sesuai dengan penjelasan diatas. Bahwa hasil uji ANAVA dua jalur pada pengaruh model pembelajaran terhadap hasil belajar siswa menunjukkan bahwa ada pengaruh yang signifikan diperoleh $F_{\text {hitung }}>F_{\text {tabel }}$ yaitu $25,269>2,50$ serta nilai probabilitas $0,000<0,05$. Dengan demikian $\mathrm{H}_{0}$ ditolak dan $\mathrm{Ha}$ diterima, sehingga disimpulkan ada pengaruh yang signifikan dengan penggunaan strategi pembelajaran terhadap hasil belajar siswa pada materi sistem pencernaan makanan manusia di MAS Amaliyah Sunggal.

Hasil uji ANAVA dua jalur menunjukkan bahwa minat belajar siswa mempunyai pengaruh signifikan terhadap hasil belajar siswa yang diperoleh $\mathrm{F}_{\text {hitung }}>\mathrm{F}_{\text {tabel }}$ yaitu $13,888>2,50$ serta nilai probabilitas $0,000<0,05$. Dengan demikian $\mathrm{H}_{0}$ ditolak dan $\mathrm{Ha}$ diterima, sehingga disimpulkan ada pengaruh yang signifikan dengan minat belajar siswa terhadap hasil belajar siswa pada materi sistem pencernaan makanan manusia di MAS Amaliyah Sunggal.

Hasil uji ANAVA dua jalur menunjukkan bahwa interaksi antara model pembelajaran dan minat belajar siswa mempunyai pengaruh signifikan terhadap hasil belajar siswa yang diperoleh $\mathrm{F}_{\text {hitung }}>\mathrm{F}_{\text {tabel }}$ yaitu $4,291>2,50$ serta nilai probabilitas memiliki minat lebih tinggi cenderung lebih baik dalam menyelesaikan masalah dan melalui pemecahan masalahmasalah tersebut siswa dapat mengembangkan kemampuan berpikir kritis mereka.

Meningkatkan kemampuan berpikir kritis siswa dalam belajar perlu dikembangkan minat belajar siswa. Peningkatan minat belajar siswa dapat dilakukan guru dengan menggunakan strategi pembelajaran berbasis masalah. Menurut Sadirman (2010), bahwa anak yang memiliki minat atau dorongan keinginan untuk belajar memiliki ciri-ciri sebagai berikut: (1) Tekun menghadapi tugas dan bekerja keras; (2) Rajin dan tidak putus asa dalam menghadapi kesulitan; (3) Menunjukkan minat terhadap bermacammacam masalah; (4) Dapat mempertahankan pendapatnya kalau sudah yakin akan sesuatu; dan (5) Senang mencari dan memecahkan masalah. Strategi pembelajaran berbasis masalah memberikan siswa kemudahan dalam memahami materi pelajaran biologi. Hal ini dikarenakan, pembelajaran berbasis masalah memberikan siswa tanggung jawab untuk membentuk dan mengarahkan pembelajaran. Hal ini dapat dilakukan guru dalam penerapan strategi pembelajarann berbasis masalah di kelas. Selain itu, strategi pembelajaran berbasis masalah mengharuskan siswa untuk mencari masalah belajar dan menuntut siswa untuk mempresentasikan apa yang telah mereka pelajari. Dengan demikian, strategi pembelajaran berbasis masalah yang digunakan guru dapat memberikan minat atau keinginan siswa untuk berpikir dengan lebih baik lagi untuk memecahkan suatu masalah

Bahwa minat belajar berpengaruh terhadap hasil belajar siswa. Minat belajar merupakan salah satu hal yang perlu ada untuk mencapai hasil belajar siswa agar prestasi belajar diperoleh secara maksimal. Hal ini sejalan dengan penelitian oleh Widiyanto (2007), menyatakan bahwa ada pengaruh positif dan signifikan dari minat belajar terhadap prestasi belajar siswa. Minat belajar menjadi daya dan kekuatan yang ada dalam diri seseorang untuk mendorong, menggerakkan, membangkitkan semangat untuk memberi perubahan perilaku agar menjadi lebih baik. Setiap siswa memiliki minat belajar meskipun tingkat kadar masing-masingnya berbeda dalam mengikuti proses pembelajaran. Mengingat pentingnya peranan minat belajar dalam memberikan dorongan pada siswa untuk belajar, maka kondisi pembelajaran yang dihubungkan dengan karakteristik siswa dalam penelitian ini melibatkan tinggi rendahnya tingkat minat belajar siswa.

Peranan minat belajar dapat memengaruhi hasil belajar siswa. Bila minat belajar tinggi, maka kegiatan belajar 
cendrung meningkat. Artinya pembelajaran semakin aktif dan sungguh-sungguh mencapai tujuan, sebab tujuan sudah merupakan kebutuhan baginya. Hakikat minat belajar adalah dorongan internal dan eksternal pada siswa yang sedang belajar untuk mengadakan perubahan tingkah laku. Siswa yang memiliki minat belajar tinggi adalah siswa yang kondisi psikologis untuk belajarnya tinggi yang dapat meningkatkan hasil belajar. Siswa yang memiliki minat belajar rendah, tidak efektif bila mereka dibelajarkan dengan strategi.

\section{HASIL DAN PEMBAHASAN Minat Belajar Siswa}

Minat belajar siswa pada kelas pembelajaran berbasis masalah berdasarkan data dari 38 siswa memiliki rentang skor antara 76 hingga 186 dengan nilai rata-rata sebesar 134,05 dan simpangan baku 41,744. Berdasarkan hasil uji normalitas menggunakan rumus Kolmogorov-Smirnov dipeoleh bahwa data tersebut berdistribusi tidak normal $(\mathrm{P}=0,000<0,05)$. Sedangkan minat belajar siswa pada kelas konvensional berdasarkan data dari 38 siswa memiliki rentang skor antara 67 hingga 176 dengan nilai rata-rata sebesar 120,16 dan simpangan baku 40,415. Berdasarkan hasil uji normalitas menggunakan rumus Kolmogorov-Smirnov dipeoleh bahwa data tersebut berdistribusi tidak normal $(\mathrm{P}=0,000<0,05$.).

\section{Kemampuan Berpikir Kritis Siswa}

Kemampuan berpikir kritis siswa pada kelas pembelajaran berbasis masalah berdasarkan data dari 38 siswa memiliki rentang skor antara 40 hingga 72 dengan nilai rata-rata sebesar 59,47 dan standar error 1,827. Sedangkan kemampuan berpikir kritis siswa pada kelas konvensional berdasarkan data dari 38 siswa memiliki rentang skor antara 31 hingga 72 dengan nilai rata-rata sebesar 52,34 dan standar error 1,652.

\section{Uji Normalitas Hasil Belajar Siswa}

Pengujian dilakukan untuk melihat apakah data hasil terdistribusi secara normal atau tidak. Setelah dilakukan pengolahan data hasil belajar siswa, dapat disimpulkan bahwa tes berdistribusi normal dan tidak normal. Hal tersebut diperjelas dengan hasil perhitungan normalitas pada hasil belajar siswa dengan menggunakan program SPSS 21.0 for windows.

Berdasarkan hasil uji normalitas data hasil belajar siswa menggunakan Kolmogorov-Smirnov, diketahui bahwa data pretes dan postes hasil belajar siswa untuk kelas strategi pembelajaran berbasis masalah dengan minat tinggi dan rendah diperoleh nilai signifikansi berdistribusi secara normal $(\mathrm{P}>0,05)$. Data pretes dan postes hasil belajar siswa untuk kelas konvensional dengan minat tinggi diperoleh nilai signifikansi berdistribusi secara normal $(\mathrm{P}>0,05)$. Data pretes hasil belajar siswa untuk kelas konvensional dengan minat rendah diperoleh nilai signifikansi berdistribusi secara normal ( $>>0,05)$, sedangkan data postes hasil belajar siswa untuk kelas konvensional dengan minat rendah diperoleh nilai signifikansi berdistribusi tidak normal $(\mathrm{P}<0,05)$.

\section{Uji Homogenitas Berpikir Kritis Siswa}

Uji homogenitas menggunakan uji Levene's dengan kriteria pengujian jika signifikansi yang diperoleh $\mathrm{P}>0.05$, maka varians antar pasangan kelompok data homogen dan jika signifikasnsi yang diperoleh $\mathrm{P}<0.05$, maka varians data tidak homogen. Hasil perhitungan homogenitas data berpikir kritis. Diperoleh bahwa hasil uji ANAVA dua jalur pada pengaruh model pembelajaran terhadap kemampuan berpikir kritis siswa menunjukkan bahwa ada pengaruh yang signifikan diperoleh $F_{\text {hitung }}>F_{\text {tabel }}$ yaitu $6,971>2,50$ serta nilai probabilitas $0,010<0,05$. Dengan demikian $\mathrm{H}_{0}$ ditolak dan $\mathrm{Ha}$ diterima, sehingga disimpulkan ada pengaruh yang signifikan dengan penggunaan model pembelajaran terhadap kemampuan berpikir kritis siswa pada materi sistem pencernaan makanan manusia di MAS Amaliyah Sunggal.

Hasil uji ANAVA dua jalur menunjukkan bahwa minat belajar siswa mempunyai pengaruh signifikan terhadap kemampuan berpikir kritis siswa yang 
diperoleh $F_{\text {hitung }}>F_{\text {tabel }}$ yaitu 24,949>2,50 serta nilai probabilitas $0,000<0,05$. Dengan demikian $\mathrm{H}_{0}$ ditolak dan $\mathrm{Ha}$ diterima, sehingga disimpulkan ada pengaruh yang signifikan dengan minat belajar terhadap kemampuan berpikir kritis siswa pada materi sistem pencernaan makanan manusia di MAS Amaliyah Sunggal.

Hasil uji ANAVA dua jalur menunjukkan bahwa interaksi antara model pembelajaran dan minat belajar siswa mempunyai pengaruh signifikan terhadap kemampuan berpikir kritis siswa yang diperoleh $\quad F_{\text {hitung }}>F_{\text {tabel }}$ yaitu $4,140>2,50$ serta nilai probabilitas $0,046<0,05$. Dengan demikian $\mathrm{H}_{0}$ ditolak dan $\mathrm{Ha}$ diterima, sehingga disimpulkan bahwa ada pengaruh interaksi model pembelajaran dan minat belajar yang signifikan terhadap kemampuan berpikir kritis siswa pada materi sistem pencernaan makanan manusia di MAS 0,042<0,05. Dengan demikian $\mathrm{H}_{0}$ ditolak dan $\mathrm{Ha}$ diterima, sehingga disimpulkan bahwa ada pengaruh interaksi model pembelajaran dan minat belajar yang signifikan terhadap hasil belajar siswa pada materi sistem pencernaan makanan manusia di MAS Amaliyah Sunggal.

Berdasarkan data strategi, minat, dan interaksi strategi pembelajaran dengan minat diperoleh nilai signifikan $\mathrm{P}<0,05$ yang berarti bahwa ada pengaruh yang signifikan terhadap hasil belajar siswa sesuai dengan penjelasan diatas.

\section{Pembahasan}

Berdasarkan hasil penelitian bahwa penggunaan strategi pembelajaran berbasis masalah lebih baik dari pada pembelajaran konvensional dalam meningkatkan kemampuan berpikir kritis siswa. Strategi pembelajaran berbasis masalah memiliki serangkaian aktivitas pembelajaran yang menekankan pada proses penyelesaian masalah yang dihadapi secara ilmiah. Implementasi strategi pembelajaran berbasis masalah ada sejumlah kegiatan yang harus dilakukan siswa. Strategi pembelajaran tersebut memberikan keharusan dalam menyelesaikan suatu masalah secara bernalar dan berkala.
Bahwa minat belajar berpengaruh terhadap kemampuan berpikir kritis siswa. Minat belajar adalah dorongan internal dan eksternal pada siswa yang sedang belajar untuk mengadakan perubahan tingkah laku, pada umumnya dengan beberapa indikator atau unsur yang mendukung untuk semangat dalam belajar sehingga dapat meningkatkan prestasi belajar yang maksimal. Siswa yang dalam materi pelajaran.

Untuk meningkatkan hasil belajar biologi, guru dapat melakukan kegiatan belajar yang melatih pengetahuan dan pemahaman terhadap materi pelajaran biologi. Peningkatan pengetahuan dan kemampuan memberikan siswa kemajuan dalam hasil belajar biologi. Untuk meningkatkan pengetahuan dan pemahaman siswa dalam pelajaran biologi, guru dapat menerapkan strategi pembelajaran berbasis masalah. Pembelajaran strategi berbasis masalah menuntut siswa untuk mampu menuangkan apa yang ada dalam pikirannya dalam bentuk kata-kata yang disampaikan dengan kemampuan lisan. Dengan adanya strategi pembelajaran berbasis masalah siswa yang memiliki minat belajar tinggi akan memiliki hasil belajar yang lebih baik dan maksimal. Dengan demikian dapat dinyatakan bahwa penggunaan strategi pembelajaran berbasis masalah dapat meningkatkan hasil belajar siswa. Hal ini sesuai dengan penelitian oleh Setiawan (2008), yang menyatakan bahwa pembelajaran berbasis masalah dapat meningkatkan hasil belajar siswa dalam pembelajaran biologi.

Pembelajaran berbasis masalah yang dilakukan guru dalam proses pemebelajaran untuk mempermudah materi pelajaran pada hal-hal dalam dunia siswa sehari-harinya. Selain itu, dengan strategi pembelajaran berbasis masalah guru dapat menuntun siswa untuk bisa menuju pada pemecahan masalah belajarnya serta untuk menampilkan apa yang telah mereka pelajari melalui hasil belajarnnya di depan kelas. 


\section{DAFTAR PUSTAKA}

Adesoji, A.F. (2008). Students Ability Levels and Effectiveness of Problem-Solving Instructional Strategy. Journal Social Science, 17(1): 5-8.

Afcariono, M. (2008). Penerapan Model pembelajaran PBL untuk Meningkatkan Kemampuan Berpikir Kritis Siswa pada Mata Pelajaran Biologi. Jurnal Pendidikan Inovatif. 3(2): 65-68

Ahmadi, A.H. (2003). Psikologi Umum. Jakarta: Rineka Cipta.

Akcay, B. (2009). Problem-Based Learning in Science Education. Journal of Turkish Science Education, 6(2): 26-36.

Allen, D. and Tanner, K. (2003). Approaches to Cell Biology Teaching: Learning Content in Contex-Problem-Based Learning.

Allen, D. And Tanner, K. (2005). Infusing Active Learning into the Large-Enrollment Biology

Amir, T. (2009). Inovasi Pendidikan Melalui Problem Based Learning. Jakarta: Kencana Prenad Media Group.

Anderson, L.W., M.S. Mitchell., dan P.M. Osgood. (2008). Gauging The Gaps In Student Problem Solving. CBE Life Science Education, 7(2): 254-262.

Anderson, O. W. and Krathwohl, David. R. (2001). Taxonomy for Learning, Teaching, and Assesing. A Revision of Bloom's Taxonomy of Educational Objectives. Abridged Edition. New York: Addison Wesley Longman, Inc.

Angkowo, R., and Kosasih, A. (2005). Optimalisasi Media Pembelajaran. Jakarta: Grasindo.

Arends, I.A. (2008). Learning to Teach. Yogyakarta: Pustaka Pelajar.

Arikunto, S. (1996). Prosedur Penelitian: Suatu Pendekatan Praktek. Jakarta: Rineka Cipta.

Arikunto, S. (2012). Dasar-Dasar Evaluasi Pendidikan Edisi 2. Jakarta: Bumi Aksara.

Armbruster, P., Patel, M., Johnsosn, E., Weiss., M. (2009). Active Learning and Student Centered Pedagogy Improve Student Attitudes and Perfonnance in Introductory Biology. CBE-Life Sciences Education, 8(1): 203-213.

Armstrong, N., Chang. M.S., Brickman, M. (2007). Cooperative Learning in IndustrialSized Biology Classes. CBE-Life Sciences Education, 6(1): 163-177.

Arsyad. (2005). Media Pembelajaran. Jakarta: Rajawali Press Indonesia.

Ary, D., Jacobs, L.C. and Razavieh, A. Tanpa Tahun. Pengantar Penelitian Pendidikan.
Terjemahan Oleh Arief Furchan. (1982). Surabaya: Usaha Nasional.

Astra dan Sumiati. (2008). Metode Pembelajaran. Bandung: Wacana Prima.

Ausubel, D.P. (1963). The Psychology of Meaningful Verbal Learning. New York: Grune and Stration.

Bao, L. (2006). Theorical Comparisons of Average Normalized Gain Calculation. American Journal Physic, 74(10): 917-922.

Barret, T. (2005). Understanding ProblemBased Learning. Dalam Handbook of Enquiry and Problem Based Learning. Galway: CELT.

Buchari. (1985). Psikologi Pendidikan. Jakarta: Aksara Baru.

Chin, C. and Gek, L.C. (2003). Implementing Problem Based-Learning in Biology. Tersedia pada: pbl.tp.edu.ag/PBL Subjects/ Articles/ ChristineChinliGekChia.pdf diakses pada tanggal 5 Maret 2014.

Class: Seven Strategies, from the Simple to Complex.

Cooper, M. (2004). Illustrated Dictionary of Education. New Delhi: Lotus Press.

Dahar, R. W. (1989). Teori-teori Belajar. Bandung: Erlangga.

Dike, W and Reiser, A.R (1996). Instructional Planning. Asimon and Schuster Company, Needham Heights, Masaschussetts.

Dimyati dan Mudjiono. (2009). Belajar dan Pembelajaran. Jakarta: Kerjasama Departemen Pendidikan dan Kebudayaan dengan Rineka Cipta.

Djamarah, S.B., dan Zain, A. (2006). Srategi Belajar Mengajar. Jakarta: Rineka Cipta.

Driscoll, M.P. (1994). Psychology of Learning for Instruction. Boston: Allyn and Bacon, Inc.

Eggen. P.D., and Kauchak. D.P. (1996). Strategiesfor Teacher. Teaching Contens and Thinking Skill. Boston: allyn and Bacon.

Ennis, R.H. (1985). A Logical Basis for Measuring Critical Thinking Skill. Educational Leadership, 43(2): 4448.Gagne. R.M. (1977). The Condition of Learning. Third Edition. New York: Holt Rinehart and Winston.

Gerlach, Vermon S and Donald P. Ely. (1980). Teaching and Media: A Systematic Approach. Seccond Edition. New Jersey: Prentice Hall, Inc.

Hamalik, O. (2009). Proses Belajar Mengajar. Jakarta: Bumi Aksara.

Hamid, A. (2007). Teori Belajar dan Pembelajaran. Program Pascasarjana Universitas Negeri Medan. 
Hardjana. (1994). Kiat Sukses di Perguruan Tinggi. Yogyakarta: Kanisius.

Hasnawiyah. (2011). Minat dan Motivasi Siswa terhadap Jurusan Biologi pada SMA di Ujungpandang. Skripsi. Ujungpandang: FMIPA IKIP.

Jubjiati. (2011). Pengaruh Model Pembelajaran PBL terhadap Hasil Belajar Biologi dan Kemampuan Berpikir Kritis Siswa SMAN 1 Batang Kuis. Tesis. Medan: Pascasarjana, Universitas Negeri Medan.

Kusnadi dan D. Priyandoko. (2007). Biologi untuk SMA dan MA Kelas XI Jilid 2. Jakarta: Piranti.

Loekmono. (1994). Belajar Bagaimana Belajar. Jakarta: Badan Pengawas Keuangan Gunung Mulia.

Lubis, R. Manurung, B. (2010). Pengaruh Model dan Media Pembelajaran terhadap Hasil Belajar dan Retensi Siswa pada Pelajaran Biologi di SMP Swasta Muhammadiyah Serbelawan. Tesis. Program Pascasarjana. Medan: Universitas Negeri Medan.

Mulyasa. (2006). Kurikulum Tingkat Satuan Pendidikan, Bandung: Remaja Rosdakarya.

Nasution, S. (2003). Teknologi Pendidikan. Bandung: Jammars.

O'Day, D. H. (2007). The Value of Animation in Biology Teaching: A Study of Long Term Memory Retention. CBE Life Science Education, 6(1): 217-223.

Pokay, P., and Blumenfeld, P.C. (1990). Predicting Achievement Early and Late in the Semester: The Role of Motivation and Use of Learning Strategies. Journal of Educational Psychology, 82(2): 42-50.

Porter. De Bobbi dan Hernacki. (1999). Quantum Learning: Membiasakan Belajar
Nyaman dan Menyenangkan. Bandung: Kaifa.

Priadi, A., dkk. (2009). Biologi Bilingual kelas XI. Jakarta: Yudistira.

Rusman. (2012). Model-Model Pembelajaran. Jakarta: PT. Raja Grafindo Tinggi.

Sadirman, A.M. (2010). Interaksi dan Minat Belajar Mengajar. Jakarta: Grafindo.

Sanjaya, W. (2011). Strategi Pembelajaran Berorientasi Standar Proses Pendidikan. Jakarta: Kencana Prenada Media Group.

Setiawan, I.G.A.N. (2008). Penerapan Pengajaran Kontekstual Berbasis Masalah untuk Meningkatkan Hasil Belajar Biologi Siswa Kelas X2 SMA Laboratorium Singaraja. Jurnal Penelitian dan Pengembangan pendidikan, Lembaga Penelitian Undiksha, 2 (1): 42-59.

Slameto. (2003). Belajar dan Faktor-Faktor yang Mempengaruhinya. Jakarta: PT. Rineka Cipta.

Snelbecker, G.E. (1984). Learning Theory and Instructional, Theory and Psychoeducational Design. New York: McGraw Hill.

Sudarman. (2005). Problem Based Learning Suatu Model Pembelajaran Untuk Mengembangkan dan Meningkatkan Kemampuan Memecahkan Masalah. FKIP: Universitas Mulawarman Samarinda.

Sudarmono. (1994). Tuntunan Metodologi Belajar. Jakarta: Grasindo.

Sudjana. (2005). Strategi Pembelajaran. Cetakan Keempat. Edisi Revisi. Bandung: Falah Production.

Syamsuri, I. (2002). Biologi $2 A$ untuk SMU Kelas 2 Semester 1. Jakarta: Erlangga. 